\title{
Managing Sacral Giant Cell Tumor with Surgery and Various Adjuvant Therapies
}

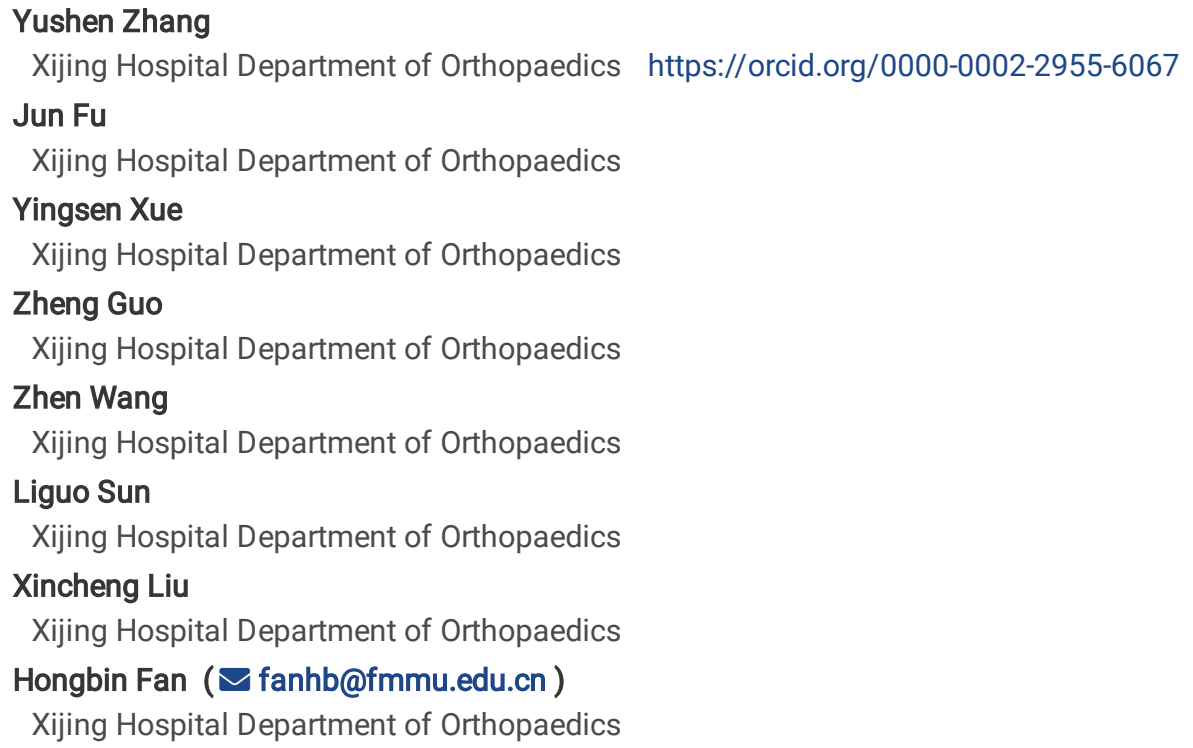

\section{Research}

Keywords: giant cell tumor, sacrum, denosumab, serial arterial embolization

Posted Date: August 7th, 2020

DOI: https://doi.org/10.21203/rs.3.rs-53987/v1

License: (c) (i) This work is licensed under a Creative Commons Attribution 4.0 International License. Read Full License 


\section{Abstract}

Background and purpose: There is no consensus regarding the appropriate treatment of sacral giant cell tumor (SGCT). This study is to compare oncological and neurological outcomes of SGCT managed by surgery and various adjunctive therapies.

Methods: A total of 31 patients with SGCT were retrospectively studied. They were divided into two Groups. A: 13 patients underwent surgery plus SAE and radiotherapy; Group B: 18 patients underwent surgery plus one arterial embolization and denosumab. The postoperative functional outcomes, recurrence, mortality, and complications were compared.

Results: The mean operation time $(231 \pm 49 \mathrm{~min})$ and blood loss $(3167 \pm 856 \mathrm{~mL})$ of group B were significantly less than those of group A $(283 \pm 41 \mathrm{~min}, 5054 \pm 689 \mathrm{~mL})(\mathrm{p}<0.05)$. The average follow-up was $68.5 \mathrm{months}$. The neurologic function scores showed no significant difference. The recurrence rate of group B $(11.2 \%)$ was much lower than that of group $A(30.7 \%, p=0.17)$. The cumulative survival rate of group $B$ was higher than that of group $A(p=0.133)$.

Conclusions: In comparison to other adjuvant therapies, one arterial embolization plus denosumab can reduce the intra-operative blood loss, shorten the operation time, and decrease the recurrence rate in patients with SGCT.

\section{Introduction}

Giant cell tumor of bone (GCTB), accounting for about $4-5 \%$ of all primary bone tumors, is an intermediate, primary bone tumor with local aggressiveness[1-2]. The sacrum is the fourth most common site, accounting for $2-8 \%$ of all cases[3-4]. Sacral giant cell tumor (SGCT) tends to be asymptomatic in the initial stage until it obtains a very large size[5]. Symptoms in severely affected patients include sacrococcygeal paresthesia, bowel or bladder dysfunction, and lower extremity weakness $[3,6,7]$. Due to huge tumor size, complex structure, and massive bleeding, SGCT surgery represents a challenge even for experienced oncology surgeon[8].

Currently, there is no agreement regarding SGCT treatment [9-11]. Surgery including curettage and en bloc excision has long been the primary treatment. For preserving sacral nerve roots, complete excision cannot be easily achieved for sacrum 3 or above involvement. Intralesional curettage is usually associated with a high local recurrence rate of $30-50 \%$. The serial arterial embolization (SAE) can be used neoadjuvantly to facilitate curettage. It has been confirmed to decrease tumor vascularization, prevent tumor progression, and relieve pain[11-14]. The disadvantage is that patients may require multiple sessions of embolization. Radiotherapy used as adjuvant treatment for residual or recurrent disease has shown promising results. However, it has possible deleterious effects including pathological fractures, neuritis, and radiationrelated sarcomas[8]. Therefore, how to further reduce the local recurrence rate is still a difficult problem.

Denosumab, a novel human monoclonal antibody that specifically inhibits receptor activator for nuclear factor-KB ligand (RANKL), can reduce the osteoclast-induced bone resorption[15]. The patients with surgically unsalvageable tumors, such as sacral or spinal GCTB, or multiple lesions, including pulmonary metastases were reported to have good response to denosumab treatment [16]. The drug shows good disease control and long-term safety [17]. Till now, few studies have investigated the effects of neoadjuvant and adjuvant denosumab therapy on SGCT management[18]. We hypothesize that preoperative use of denosumab can reduce the surgical difficulty for nerve-sparing procedure and postoperative use of denosumab can improve prognosis in SGCT patients.

In this retrospective study, we report our experience on 31 patients of managing SGCT by surgery with respective adjuvant therapies including SAE plus radiotherapy and SAE plus denosumab. The aim of this study is to compare the effectiveness (local recurrence; metastasis) and efficiency (blood loss; operation time) of these adjuvant therapies.

\section{Patients And Methods}

\section{Patients}

This retrospective study was approved by Institutional Review Board of the Xi-jing hospital and carried out in accordance with the relevant guidelines and regulations. All cases were from clinical database of our center. The inclusion criteria included: (1) histological diagnosis; (2) primary surgery underwent in our department; (3) no evidence of metastasis; (4) clinical features and follow-up data were precisely recorded. A total of 31 patients with previously untreated, histologically confirmed SGCT were enrolled between January 2008 and December 2018 . All patients had a minimum 2-year follow-up. The demographic and clinical characteristics of all patients are detailed in Table 1. The patients comprised 14 males and 17 females. The median age of the patients was 36 years, ranging from 15 to 54 years. They were divided into two groups according to treatments, Group A $(n=13)$ : surgery with SAE and postoperative radiotherapy; Group B (n=18): surgery with one arterial embolization and denosumab.

\section{Surgery and Adjuvant Therapies}


In group A, the patients received SAE before surgery. The feeder arteries were identified by selective angiography and arterial embolization was performed. Thereafter, the patient underwent further angiography at 2-3 intervals with embolization of any new major vessels. Usually a total of 3-4 embolization was needed in each patient. Then, the patients were treated with curettage and postoperative radiation (total dose: $40-50 \mathrm{~Gy}$ ).

Considering the significant role in treating GCTB, denosumab was used as neoadjuvant and adjuvant therapy to treat SGCT in group B. The denosumab (120mg) was administrated on day 1, 8, and 15 before operation. Then, the patients received selective angiography. The vascularization of tumor lesion was not rich in most cases after denosumab treatment. One arterial embolization was performed to block the residual vessels. Thereafter, the patient underwent surgery within the third week and postoperative radiotherapy was not needed. The subcutaneous denosumab (120mg) was given every 4 weeks till 2 years. Thereafter, the denosumab treatment was ceased. The patients should take daily supplements of calcium $(>500 \mathrm{mg})$ and vitamin D (>400 IU)throughout the treatment course.

The surgical procedure consisted of intralesional excision and curettage. The excision was performed on tumor portion that was distally located (below S3) in sacrum. For the tumor portion involving S3 or above, patients underwent intralesional curettage. The tumor lesion was carefully peeled from sacral nerves. The nerve roots were identified and preserved as much as possible. No other adjuvant such as high-speed bur, bisphosphonate cement, phenol, etc. was used intraoperatively. After removal of tumor tissue, the remaining spinopelvic stability was intraoperatively assessed. If at least the cephalad, $50 \%$ of sacroiliac joints were bilaterally preserved, no reconstruction was needed. Otherwise, the posterior fixation by pedicle screws combined with iliac screws was performed.

\section{Follow-up and Evaluation}

The patients were examined every 3 months for the first 2 years, then every 6 months between 2 and 5 years, and annually thereafter. The

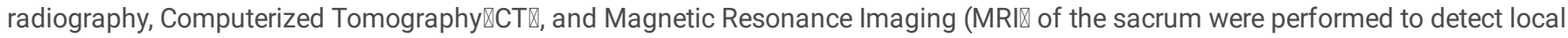
recurrence. Chest CT was also required to detect metastasis. The bowel, bladder, and motor function were assessed at 12 months postoperatively according to the scoring method reported by Biagini et al[19].This scoring system has three items: bladder function, bowel function, and motor function. Each item is allocated 0 to 2 points according to the degree of functional impairment with 2 indicating poor and 0 indicating excellent functional result.

\section{Statistical Analysis}

The data analysis was performed with SPSS software (version 17.0; IBM Corp., Armonk, NY). The operating duration, intraoperative blood loss, and neurologic function score were compared among groups by One-way ANOVA. The recurrence rates between groups were compared by Chisquared test. The disease-free survival rate was estimated by Kaplan-Meier survival analysis. The $P$ value $<0.05$ was considered significant.

\section{Results}

\section{Operation Time and Blood Loss}

In group $B$, the mean operation time and blood loss were $231 \pm 49 \mathrm{~min}$ and $3167 \pm 856 \mathrm{~mL}$ respectively, which were significantly less than those of group A (283 $\pm 41 \mathrm{~min}, \mathrm{p}=0.002 ; 5054 \pm 689 \mathrm{~mL}, \mathrm{p}<0.001)$ (Fig.1).

\section{Follow-Up Results}

The average follow-up time was 68.5 months, ranging from 24 to 131 months. All patients were alive at the final follow-up. After primary surgery, four out of 13 patients had local recurrence in group $A$ and 2 out of 18 in group $B$. The recurrent patients underwent repeat curettage after SAE treatment. Then, the radiotherapy or denosumab was required to control recurrence. At the latest follow-up, there was no repeat recurrence. There was no metastatic patient in current study. The mean time to first recurrence was 17.6 months ranging from 12 to 24 months. The recurrence rate of group B (11.2\%) was much lower than that of group A (30.7\%) although there was no significant difference ( $p=0.17)$. The neurologic function scores were $0.46 \pm 0.52$ and $0.50 \pm 0.51$ in group $A$ and $B$, respectively. There was no significant difference between groups. Disease-free survival was estimated according to the Kaplan-Meier method. There was no significant difference between group A and B $(p=0.133$, Fig. 2).

Complications included infection and wound dehiscence. After surgery, 6 cases received wound debridement because of wound dehiscence. Internal fixation was removed in one patient due to deep infection. The ONJ was not observed in denosumab treatment group.

\section{Typical cases}

Case\#9: A 36-year-old female presented with severe pain in her right buttock for 6 months. Radiograph and MRI revealed a massive tumor involving sacrum 1-3, which extended into extraosseous soft tissue. The histological diagnosis was SGCT. SAE was performed for 3 sessions with 3-week interval until tumor's vascularity disappeared. After completion of the 3rd embolization, the buttock pain resolved significantly. 
Then, the meticulous curettage was performed and intraoperative blood loss was 5500mL (Fig.3). The spinopelvic stability was reconstructed by posterior fixation using pedicle screws and iliac screws. The post-operative pathology revealed the partial response to SAE treatment. The giant cell number wasn't significantly reduced (Fig. 3G, 3H). The postoperative radiotherapy (total dose: $45 \mathrm{~Gy}$ ) was also needed. Aided by these multimodality treatments, the patient recovered successfully and was free from disease.

Case\#23: A 22-year-old female presented with fast progress of sacrococcygeal pain and dyschezia for 3weeks. A large mass with cortical destruction was shown in MRI and X-ray. Both arterial embolization and denosumab were used to control tumor progress and relieve symptoms. Three doses of denosumab (120mg per dose) were administrated on day 1, 8, and 15 before operation. Then, the patients received selective angiography. The image showed there was no rich vascularization in tumor lesion. One arterial embolization was performed to block the residual blood supply within tumor (Fig.4). Thereafter, intralesional curettage was performed and intraoperative blood loss was $2200 \mathrm{~mL}$. The postoperative pathological slides demonstrated significant response to denosumab which was indicated by paucity of giant cells and abundant production of fibro-osseous tissue (Fig.4G, 4H). The patient received postoperative denosumab treatment and had satisfactory recovery at final follow-up.

\section{Discussion}

In group A, SAE was used as preoperative treatment for SGCT in this study. It could relieve pain by ossification in tumor. However, no obvious evidence indicated it could decrease the tumor size $[12,20]$. Denosumab could inhibit RANK-RANKL interactions and prevent GCTB-induced bone destruction. Recently, it has played a significant role in treating unsalvageable GCTB [15]. The tumor's metabolic activity, blood supply, and volume was reported to decrease after preoperative use of denosumab [21]. A nonrandomized controlled study of SGCT with preoperative denosumab treatment indicated that intraoperative blood loss was significantly reduced [22].

In current study, the operation time and blood loss of Group B (curettage + one arterial embolization + denosumab) were significantly less than those of Group A. The effects of denosumab were consistent with previous reports [21, 23]. The preoperative use of denosumab could reduce tumor's blood supply [20], which was demonstrated by angiography in current study. It was speculated that denosumab had inhibitory effect on endothelial growth factor, thus decreased endothelial proliferation[24]. The decreased blood supply was helpful to acquire clearly visible operation field, which facilitated the meticulous curettage[25]. However, the span of preoperative denosumab treatment is of great importance. In present study, we followed the protocol reported by Chawla et al [26]. The patients underwent surgeries within the third week after denosumab (120 mg) administration on day 1, 8, and 15 before operation. The literature indicated that overlong pretreatment could increase the bony septa and form the dense fibrous tissue adhered to sacral nerves. It was difficult to separate the nerves from tumor [9].

Very few studies have been published regarding histopathologic changes in post-denosumab treated tumor specimens. In present study, the pre-operative biopsy showed multinucleated giant cells with uniform vesicular nucleus and mononuclear cells with spindle shape[27, 28]. The post-operative histology of specimens showed the giant cell numbers decreased significantly and cells nearly disappeared in 9 cases. Meanwhile, the osteoblast-like cells appeared and produced a large amount of fibro-osseous tissue (Fig. 4G, 4H). Rekhi et al [29] reported the similar results. Twenty-seven post denosumab-treated tumors were analyzed. They observed complete absence of giant cells in 15 cases and marked reduction (more than 90\%) of giant cells in 9 cases. Compared with our results, their specimens showed more reduction or elimination of RANK-positive tumor giant cells. The reason maybe that most patients (16) (59.2\%) received 6 doses of denosumab in their study. Only 3 doses were used in our study considering the feasibility of performing curettage to avoid dense fibrous adhesion.

The reported recurrence, metastasis, and complications of SGCT patients were summarized in Table 2. Local recurrence was reported to occur in $10-66.7 \%$ of patients. The effects of SAE and radiotherapy on recurrence control are controversial. Ruggieri et al [30] reported 31 SGCT patients and three (10\%) had local recurrence within 34 months from initial treatment. Survival to local recurrence with and without radiation was $91 \%$ and $89 \%$, with and without embolization was $91 \%$ and $86 \%$ respectively. Adjuvants had no influence on local recurrence. Domovitov et al. [18] reported 24 SGCT patients and local recurrence rate was $30 \%$. Radiation and preoperative embolization were associated with prolonged disease-free survival. There was no local recurrence among the 11 patients who were treated with both modalities. Regarding to the effect of denosumab, Yang et al.[22] reported that six patients received preoperative denosumab treatment for 5.2 months. After 12 months of follow-up, the recurrence rate was relatively high (66.7\%). The authors thought the newly formed bone induced by denosumab raised a new surgical challenge by not allowing surgeon to delineate the true extent of tumor. The tumor cells might hide within the new osseous matrix. In present study, the recurrence in denosumab treatment group was 2 in 18 cases (11.1\%), which was much lower than that of group A. The results were similar to the data reported by Chen et al. [21]. This rate was lower than most rates previously reported by using other adjuvant therapies [3133]. Recently, Lim et al. [34] evaluated therapeutic benefits of denosumab on nerve-sparing surgery in SGCT. They reported the similar local recurrence rate $(3 / 17,17.6 \%)$ in neo- and adjuvant denosumab group. In addition to correlating their results, this study indicated neo-adjuvant denosumab treatment could decrease the tumor's blood supply and thereby reduce the number of arterial embolization. The low recurrence rate in current study could be explained by aggressive curettage performed in clearly visible operation field due to the decrement of tumor's blood supply after denosumab treatment. 
At the present time, it is important to confirm whether the treatment with denosumab can be safely maintained in the long term. Chawla et al [26] investigated 532 patients with the median follow-up of 58.1 months in a multicenter, open-label, phase 2 study. Patients received 120 mg subcutaneous denosumab once every 4 weeks during the treatment phase. The most common adverse events were hypophosphataemia (24, $5 \%)$ and ONJ (17,3\%). However, no case of hypophosphataemia and ONJ was observed in our study. The reasons might lie in: 1) Patients with a history or current evidence of osteonecrosis or osteomyelitis of the jaw were excluded; 2 ) The included patients were told to avoid oral operation during the period of denosumab treatment; 3 ) Patients took daily supplements of calcium (>500 mg) and vitamin D (> 400 IU) to prevent hypocalcemia. Another severe complication is sarcomatous transformation. The first case with sarcomatous transformation after denosumab treatment was reported by Aponte-Tinao et al in 2015[35]. Thereafter, other studies also reported such complication with the frequency ranging from $1-2 \%[16,26,36]$. Although there is no clear association between malignancy and denosumab treatment, these findings suggest radiological and pathological examinations should monitor the sarcomatous change. There was no patient with sarcomatous transformation in our study, which might be attributed to the small sample size.

The authors acknowledge several limitations in present study. Firstly, this is the retrospective study, which might induce information bias despite being one of the large series on the denosumab treatment SGCT; Secondly, perhaps given the relatively small sample size, we found no significant difference in recurrence rate between group A (surgery + SAE + radiotherapy) and B (surgery + onearterial embolization + denosumab), although the latter was much lower. Larger studies might determine that denosumab has statistically significant influence on recurrence; Thirdly, the confounding variables such as the volume, size, location, and aggressiveness of the tumors could not be controlled among groups, these factors might weaken the accuracy of the statistical analysis to some extent.

\section{Conclusions}

There have been some clinical studies which reported oncologic results of GCT after denosumab treatment, but few focuses on SGCT. Although our study has limited power owing to small numbers and uncontrolled variables, the data still suggest the curettage with one arterial embolization and denosumab can reduce the intra-operative blood loss, shorten the operation time, and decrease the recurrence rate. The use of denosumab in patients with SGCT shows good safety and long-term disease control.

\section{Abbreviation}

SGCT, sacral giant cell tumor; GCTB, Giant cell tumor of bone; SAE, serial arterial embolization; RANKL, nuclear factor-kB ligand; CT, Computerized Tomography; MRI, Magnetic Resonance Imaging.

\section{Declarations}

\section{Ethics approval and consent to participate}

The authors are accountable for all aspects of the work in ensuring that questions related to the accuracy or integrity of any part of the work are appropriately investigated and resolved.

\section{Consent for publication}

All presentations of case reports have consent for publication.

\section{Availability of data and materials}

The datasets used and/or analysed during the current study are available from the corresponding author on reasonable request.

\section{Competing interests}

No conflict of interest exists in the submission of this manuscript, and the manuscript is approved by all authors for publication.

\section{Funding}

This work was supported by National Key R\&D Program of China (No. 2016YFB1101104); Shaanxi Provincial Key R\&D Program, China \No.2018ZDXM-SF-075区.

\section{Authors' contributions}

Zhang Y: Patient evaluation, data collection, dataanalysis and manuscript writing

Fu J: Patient evaluation, data collection 
Xue Y: Data collection, dataanalysis and manuscript writing

Guo Z:Patient evaluation, data collection

Wang Z: Patient evaluation, data collection

Sun L: Patient evaluation, data collection, dataanalysis and manuscript writing and editing.

Liu X:Patient evaluation, data collection

Fan H:Supervision, patient evaluation,data collection, data analysis, manuscript editing, formalanalysis

\section{Acknowledgements}

We sincerely thank Prof. Lu Wang for her assistance in histopathology preparation.

\section{References}

1. Rockberg J, Bach BA, Amelio J, Hernandez RK, Sobocki P, Engellau J, Bauer HCF, Liede A. Incidence Trends in the Diagnosis of Giant Cell Tumor of Bone in Sweden Since 1958. J Bone Joint Surg. 2015;97(21):1756-66.

2. Raskin KA, Schwab JH, Mankin HJ, Springfield DS, Hornicek FJ. Giant Cell Tumor of Bone. J Am Acad Orthop Sur. 2013; 21(2):118-26.

3. Martin C, McCarthy EF. Giant cell tumor of the sacrum and spine: series of 23 cases and a review of the literature. The lowa orthopaedic journal. 2010;30:69-75.

4. van der Heijden L, van de Sande MAJ, van der Geest ICM, Schreuder HWB, van Royen BJ, Jutte PC, Bramer JAM, Öner FC, van NoortSuijdendorp AP, Kroon HM, Dijkstra PDS. Giant cell tumors of the sacrum-a nationwide study on midterm results in 26 patients after intralesional excision. Eur Spine J. 2014;23(9):1949-62.

5. Llauger J, Palmer J, Amores S, Bague S, Camins A. Primary Tumors of the Sacrum. Am J Roentgenol. 2000;174(2):417-24.

6. Xu W, Wang Y, Wang J, Yang X, Liu W, Zhou W, Liu T, Xiao J. Long-term administration of bisphosphonate to reduce local recurrence of sacral giant cell tumor after nerve-sparing surgery. Journal of Neurosurgery: Spine. 2017;26(6):716-21.

7. Yu X, Xu M, Xu S, Fu Z. Long-term outcome of giant cell tumor of bone involving sacroiliac joint treated with selective arterial embolization and curettage: a case report and literature review. World J Surg Oncol. 2013; 11(1):72.

8. Leggon RE, Zlotecki R, Reith J, Scarborough MT. Giant Cell Tumor of the Pelvis and Sacrum. Clin Orthop Relat R. 2004; 423:196-207.

9. Yang Y, Li Y, Liu W, Xu H, Niu X. A nonrandomized controlled study of sacral giant cell tumors with preoperative treatment of denosumab. Medicine. 2018; 97(46): e13139.

10. Ming Z, Kangwu C, Huilin Y, Genlin W, Jian L, Yiming J, Chunshen W, Chao C. Analysis of risk factors for recurrence of giant cell tumor of the sacrum and mobile spine combined with preoperative embolization. Turk Neurosurg. 2013; 23(5): 645-52.

11. van der Heijden L, Dijkstra PDS, van de Sande MAJ, Kroep JR, Nout RA, van Rijswijk CSP, Bovee JVMG, Hogendoorn PCW, Gelderblom H. The Clinical Approach Toward Giant Cell Tumor of Bone. The Oncologist. 2014;19(5):550-61.

12. Hosalkar HS, Jones KJ, King JJ, Lackman RD. Serial Arterial Embolization for Large Sacral Giant-Cell Tumors. Spine. 2007; 32(10):110715.

13. Thangaraj R, Grimer RJ, Carter SR, Stirling AJ, Spilsbury J, Spooner D. Giant cell tumour of the sacrum: a suggested algorithm for treatment. Eur Spine J. 2010;19(7):1189-94.

14. Emori M, Kaya M, Sasaki M, Wada T, Yamaguchi T, Yamashita T. Pre-operative Selective Arterial Embolization as a Neoadjuvant Therapy for Proximal Humerus Giant Cell Tumor of Bone: Radiological and Histological Evaluation. Jpn J Clin Oncol. 2012;42(9):851-5.

15. Branstetter D, Rohrbach K, Huang L, Soriano R, Tometsko M, Blake M, Jacob AP, Dougall WC. RANK and RANK ligand expression in primary human osteosarcoma. J Bone Oncol. 2015;4(3):59-68.

16. .Chawla S, Blay J, Rutkowski P, Le Cesne A, Reichardt P, Gelderblom H, Grimer RJ, Choy E, Skubitz K, Seeger L, Schuetze SM, Henshaw R, Dai T, Jandial D, Palmerini E. Denosumab in patients with giant-cell tumour of bone: a multicentre, open-label, phase 2 study. The Lancet Oncology. 2019;20(12):1719-29.

17. Maurice B. Denosumab treatment of giant cell tumour of bone. Lancet Oncol. 2013;14(9):801-2.

18. Domovitov SV, Chandhanayingyong C, Boland PJ, McKeown DG, Healey JH. Conservative surgery in the treatment of giant cell tumor of the sacrum: 35 years' experience. Journal of Neurosurgery: Spine. 2016;24(2):228-40.

19. Biagini R, Ruggieri P, Mercuri M, Capanna R, Briccoli A, Perin S, Orsini U, Demitri S, Arlecchini S. Neurologic deficit after resection of the sacrum. La Chirurgia degli organi di movimento. 1997;82(4):357.

Page 6/12 
20. Lackman RD, Khoury LD, Esmail A, Donthineni-Rao R. The treatment of sacral giant-cell tumours by serial arterial embolisation. J Bone Joint Surg Br. 2002;84(6):873.

21. Chen Z, Yang Y, Guo W, Yang R, Tang X, Yan T, Ji T, Xie L, Xu J, Wang J. Therapeutic benefits of neoadjuvant and post-operative denosumab on sacral giant cell tumor: a retrospective cohort study of 30 cases. J Buon. 2018;23(2):453-9.

22. Yang Y, Li Y, Liu W, Xu H, Niu X. A nonrandomized controlled study of sacral giant cell tumors with preoperative treatment of denosumab. Medicine. 2018;97(46):e13139.

23. Ozaki T, Liljenqvist U, Halm H, Hillmann A, Gosheger G, Winkelmann W. Giant Cell Tumor of the Spine. Clin Orthop Relat R. 2002;(401):194201.

24. Allegra A, Innao V, Pulvirenti N, Musolino C. Antiresorptive Agents and Anti-Angiogenesis Drugs in the Development of Osteonecrosis of the Jaw. The Tohoku Journal of Experimental Medicine. 2019;248(1):27-9.

25. Müller DA, Beltrami G, Scoccianti G, Campanacci DA, Franchi A, Capanna R. Risks and benefits of combining denosumab and surgery in giant cell tumor of bone-a case series. World J Surg Oncol. 2016;14(1).

26. 26. Thomas D, Henshaw R, Skubitz K, Chawla S, Staddon A, Blay J, Roudier M, Smith J, Ye Z, Sohn W, Dansey R, Jun S. Denosumab in patients with giant-cell tumour of bone: an open-label, phase 2 study. The Lancet Oncology. 2010;11(3):275-80.

27. Branstetter DG, Nelson SD, Manivel JC, Blay JY, Chawla S, Thomas DM, Jun S, Jacobs I. Denosumab Induces Tumor Reduction and Bone Formation in Patients with Giant-Cell Tumor of Bone. Clin Cancer Res. 2012;18(16):4415-24.

28. Hakozaki M, Tajino T, Yamada H, Hasegawa O, Tasaki K, Watanabe K, Konno S. Radiological and pathological characteristics of giant cell tumor of bone treated with denosumab. Diagn Pathol. 2014;9(1):111.

29. Rekhi B, Verma V, Gulia A, Jambhekar NA, Desai S, Juvekar SL, Bajpai J, Puri A. Clinicopathological Features of a Series of 27 Cases of Post-Denosumab Treated Giant Cell Tumors of Bones: A Single Institutional Experience at a Tertiary Cancer Referral Centre, India. Pathol Oncol Res.;23(1):157-64.

30. Ruggieri P, Mavrogenis AF, Ussia G, Angelini A, Papagelopoulos PJ, Mercuri M. Recurrence after and complications associated with adjuvant treatments for sacral giant cell tumor. Clin Orthop Relat Res. 2010;468(11):2954-61

31. Martin C, Mccarthy EF. Giant cell tumor of the sacrum and spine: series of 23 cases and a review of the literature. lowa Orthopaedic Journal. 2010;30:69-75.

32. Van DHL, van de Sande MAJ, van der Geest ICM, Schreuder HWB, van Royen BJ, Jutte PC, Bramer JAM, Ner FC, van Noort-Suijdendorp AP, Kroon HM. Giant cell tumors of the sacrum-a nationwide study on midterm results in 26 patients after intralesional excision. Eur Spine J. 2014; 23(9):1949-62.

33. Jamshidi K, Bagherifard A, Mirzaei A, Bahrabadi M. Giant Cell Tumor of the Sacrum: Series of 19 Patients and Review of the Literature. Arch Bone Jt Surg. 2017;5(6):443-50.

34. Lim CY, Liu X, He F, Liang H, Yang Y, Ji T, Yang R, Guo W. Retrospective cohort study of 68 sacral giant cell tumours treated with nervesparing surgery and evaluation on therapeutic benefits of denosumab therapy. Bone Joint J. 2020;102-B(2):177-85.

35. Aponte-Tinao LA, Piuzzi NS, Roitman P, Farfalli GL. A High-grade Sarcoma Arising in a Patient With Recurrent Benign Giant Cell Tumor of the Proximal Tibia While Receiving Treatment With Denosumab. Clin Orthop Relat R. 2015;473(9):3050-5.

36. Julian BC, L. GE, Jeff W, Therese B. Two Cases of Sarcoma Arising in Giant Cell Tumor of Bone Treated with Denosumab. Case Reports in Medicine.;2015:1-6.

\section{Tables}


Table 1

Demographic and clinical data of SGCT patients.

\begin{tabular}{|c|c|c|c|c|c|c|c|c|c|c|c|}
\hline $\begin{array}{l}\text { Patient. } \\
\text { No. }\end{array}$ & Group & Age(yr)/Gender & $\begin{array}{l}\text { Denosumab } \\
\text { (Pre/Post } \\
\text { OP) }\end{array}$ & $\mathrm{AE}$ & $\begin{array}{l}\text { R.T. } \\
\text { (Post } \\
\text { Op.) }\end{array}$ & $\begin{array}{l}\text { Op. } \\
\text { Time } \\
\text { (mins) }\end{array}$ & $\begin{array}{l}\text { Blood } \\
\text { loss } \\
(\mathrm{mL})\end{array}$ & $\begin{array}{l}\text { Follow- } \\
\text { up } \\
\text { (mo) }\end{array}$ & $\begin{array}{l}\text { Neurologic } \\
\text { Function } \\
\text { score }\end{array}$ & $\begin{array}{l}\text { Recurrence } \\
\text { (mo) }\end{array}$ & $\begin{array}{l}\text { Metastasis } \\
\text { (mo) }\end{array}$ \\
\hline 1 & A & $27 / M$ & $\mathrm{~N} / \mathrm{N}$ & $Y$ & $Y$ & 320 & 3700 & 96 & 1 & $Y(12)$ & $\mathrm{N}$ \\
\hline 2 & A & $20 / F$ & $\mathrm{~N} / \mathrm{N}$ & $Y$ & $Y$ & 330 & 4200 & 99 & 0 & $\mathrm{~N}$ & $\mathrm{~N}$ \\
\hline 3 & A & $54 / F$ & $\mathrm{~N} / \mathrm{N}$ & $Y$ & $Y$ & 230 & 6000 & 84 & 0 & $\mathrm{~N}$ & $\mathrm{~N}$ \\
\hline 4 & A & $24 / \mathrm{M}$ & $\mathrm{N} / \mathrm{N}$ & $Y$ & $Y$ & 250 & 4500 & 88 & 1 & $N$ & $N$ \\
\hline 5 & A & $26 / F$ & $\mathrm{~N} / \mathrm{N}$ & $Y$ & $Y$ & 310 & 5000 & 81 & 0 & $Y(15)$ & $\mathrm{N}$ \\
\hline 6 & A & $28 / F$ & $\mathrm{~N} / \mathrm{N}$ & $Y$ & $\mathrm{Y}$ & 350 & 4800 & 82 & 1 & $Y(18)$ & $\mathrm{N}$ \\
\hline 7 & A & $19 / \mathrm{M}$ & $\mathrm{N} / \mathrm{N}$ & $Y$ & $Y$ & 265 & 5200 & 90 & 0 & $N$ & $\mathrm{~N}$ \\
\hline 8 & A & $42 / F$ & $\mathrm{~N} / \mathrm{N}$ & $Y$ & $Y$ & 285 & 5400 & 131 & 1 & $\mathrm{~N}$ & $\mathrm{~N}$ \\
\hline 9 & A & $36 / F$ & $\mathrm{~N} / \mathrm{N}$ & $Y$ & $Y$ & 230 & 5500 & 122 & 1 & $N$ & $\mathrm{~N}$ \\
\hline 10 & A & $43 / F$ & $\mathrm{~N} / \mathrm{N}$ & $Y$ & $Y$ & 240 & 5400 & 122 & 0 & $Y(18)$ & $\mathrm{N}$ \\
\hline 11 & A & $50 / F$ & $\mathrm{~N} / \mathrm{N}$ & $Y$ & $Y$ & 300 & 6000 & 115 & 1 & $\mathrm{~N}$ & $\mathrm{~N}$ \\
\hline 12 & A & $47 / F$ & $\mathrm{~N} / \mathrm{N}$ & $Y$ & $Y$ & 320 & 5500 & 114 & 0 & $\mathrm{~N}$ & $\mathrm{~N}$ \\
\hline 13 & A & $45 / \mathrm{M}$ & $\mathrm{N} / \mathrm{N}$ & $Y$ & $Y$ & 250 & 4500 & 92 & 0 & $\mathrm{~N}$ & $\mathrm{~N}$ \\
\hline 14 & B & $34 / \mathrm{M}$ & $Y / Y$ & $Y$ & $\mathrm{~N}$ & 315 & 3800 & 61 & 1 & $N$ & $\mathrm{~N}$ \\
\hline 15 & B & $48 / F$ & $\mathrm{Y} / \mathrm{Y}$ & $\mathrm{Y}$ & $\mathrm{N}$ & 240 & 4000 & 66 & 0 & $\mathrm{~N}$ & $\mathrm{~N}$ \\
\hline 16 & B & $36 / F$ & $\mathrm{Y} / \mathrm{Y}$ & $\mathrm{Y}$ & $\mathrm{N}$ & 250 & 4000 & 67 & 0 & $\mathrm{~N}$ & $\mathrm{~N}$ \\
\hline 17 & B & $32 / \mathrm{M}$ & $Y / Y$ & $Y$ & $\mathrm{~N}$ & 200 & 3500 & 51 & 1 & $N$ & $N$ \\
\hline 18 & B & $38 / \mathrm{M}$ & $\mathrm{Y} / \mathrm{Y}$ & $\mathrm{Y}$ & $\mathrm{N}$ & 280 & 4300 & 28 & 0 & $\mathrm{~N}$ & $\mathrm{~N}$ \\
\hline 19 & B & $46 / \mathrm{M}$ & $Y / Y$ & $Y$ & $N$ & 280 & 3800 & 42 & 1 & $N$ & $\mathrm{~N}$ \\
\hline 20 & B & $30 / \mathrm{M}$ & $\mathrm{Y} / \mathrm{Y}$ & $\mathrm{Y}$ & $\mathrm{N}$ & 175 & 2450 & 55 & 0 & $\mathrm{~N}$ & $\mathrm{~N}$ \\
\hline 21 & B & $53 / F$ & $Y / Y$ & $Y$ & $\mathrm{~N}$ & 215 & 3500 & 44 & 1 & $N$ & $\mathrm{~N}$ \\
\hline 22 & B & $49 / F$ & $\mathrm{Y} / \mathrm{Y}$ & $\mathrm{Y}$ & $\mathrm{N}$ & 240 & 4000 & 68 & 0 & $\mathrm{~N}$ & $\mathrm{~N}$ \\
\hline 23 & B & $22 / F$ & $\mathrm{Y} / \mathrm{Y}$ & $\mathrm{Y}$ & $\mathrm{N}$ & 160 & 2200 & 30 & 0 & $\mathrm{~N}$ & $\mathrm{~N}$ \\
\hline 24 & B & $27 / F$ & $\mathrm{Y} / \mathrm{Y}$ & $Y$ & $\mathrm{~N}$ & 265 & 3500 & 60 & 1 & $Y(24)$ & $\mathrm{N}$ \\
\hline 25 & $B$ & $28 / \mathrm{M}$ & $\mathrm{Y} / \mathrm{Y}$ & $Y$ & $\mathrm{~N}$ & 170 & 2000 & 37 & 1 & $\mathrm{~N}$ & $\mathrm{~N}$ \\
\hline 26 & B & $52 / F$ & $\mathrm{Y} / \mathrm{Y}$ & $Y$ & $\mathrm{~N}$ & 210 & 2250 & 40 & 0 & $N$ & $\mathrm{~N}$ \\
\hline 27 & B & $48 / \mathrm{M}$ & $\mathrm{Y} / \mathrm{Y}$ & Y & $\mathrm{N}$ & 190 & 1800 & 24 & 1 & $Y(24)$ & $\mathrm{N}$ \\
\hline 28 & $B$ & $44 / \mathrm{M}$ & $\mathrm{Y} / \mathrm{Y}$ & $Y$ & $\mathrm{~N}$ & 235 & 4000 & 31 & 0 & $\mathrm{~N}$ & $\mathrm{~N}$ \\
\hline 29 & $B$ & $37 / \mathrm{M}$ & $\mathrm{Y} / \mathrm{Y}$ & $Y$ & $\mathrm{~N}$ & 330 & 3400 & 50 & 0 & $\mathrm{~N}$ & $\mathrm{~N}$ \\
\hline 30 & $B$ & 19/M & $\mathrm{Y} / \mathrm{Y}$ & $Y$ & $\mathrm{~N}$ & 190 & 2300 & 26 & 1 & $\mathrm{~N}$ & $\mathrm{~N}$ \\
\hline 31 & B & $15 / F$ & $\mathrm{Y} / \mathrm{Y}$ & $Y$ & $\mathrm{~N}$ & 220 & 2200 & 28 & 1 & $\mathrm{~N}$ & $\mathrm{~N}$ \\
\hline
\end{tabular}

(AE: arterial embolization, group $A$ received serial $A E$, group $B$ received one AE; R.T.: radiotherapy.) 
Table 2

पComparison of tumor control and complications of SGCT patients.

\begin{tabular}{|c|c|c|c|c|c|c|c|c|c|}
\hline $\mathbf{N}$ & Patients & $\begin{array}{l}\text { Deno. } \\
\text { (pre- } \\
\text { Op) }\end{array}$ & $\begin{array}{l}\text { Deno. } \\
\text { (post- } \\
\text { Op) }\end{array}$ & $\begin{array}{l}\text { AE/Aorta } \\
\text { balloon }\end{array}$ & RT & $\begin{array}{l}\text { FU } \\
\text { (mo) }\end{array}$ & Recur. & Meta. & Complication \\
\hline $\begin{array}{l}\text { Ruggieri et } \\
\text { al. } \\
{[30] / 2010}\end{array}$ & 31 & $\mathrm{~N}$ & $\mathrm{~N}$ & $\mathrm{Y}$ & $\mathrm{Y}$ & $\begin{array}{l}109(36- \\
276)\end{array}$ & $3(10 \%)$ & 0 & $\begin{array}{l}\text { Wound dehiscence (8); life- } \\
\text { threatening massive bleeding (7); } \\
\text { neurologic deficit }\end{array}$ \\
\hline $\begin{array}{l}\text { Martin et al. } \\
{[31] / 2010}\end{array}$ & 6 & $\mathrm{~N}$ & $\mathrm{~N}$ & $\mathrm{Y}$ & $\mathrm{Y}$ & $\begin{array}{l}24.3(0- \\
84)\end{array}$ & $\begin{array}{l}2 \\
(33.3 \%)\end{array}$ & 0 & NR \\
\hline $\begin{array}{l}\text { van der } \\
\text { Heijden L et } \\
\text { al. } \\
\text { [32]/2014 }\end{array}$ & 26 & $\mathrm{~N}$ & $\mathrm{~N}$ & $\begin{array}{l}19 \\
(73.1 \%)\end{array}$ & 3 & $98(6-229)$ & $\begin{array}{l}14 \\
(53.8 \%)\end{array}$ & $\begin{array}{l}4 \\
(15.4 \%)\end{array}$ & $\begin{array}{l}\text { Infection (3); permanent neuropraxia } \\
\text { (3); hardware failure (1); radiation- } \\
\text { induced sarcoma (1); radiation- } \\
\text { induced menopause (1); delayed } \\
\text { wound healing (1); pubic fracture (1) }\end{array}$ \\
\hline $\begin{array}{l}\text { Domovitov } \\
\text { et al. [18] / } \\
2016\end{array}$ & 24 & $\mathrm{~N}$ & $\mathrm{~N}$ & $16(67 \%)$ & 14 & $87(2-288)$ & $7(30 \%)$ & $2(8 \%)$ & $\begin{array}{l}\text { Completely lost bladder and/or bowel } \\
\text { function (3); Infection (7); Sacrum } \\
\text { fracture }\end{array}$ \\
\hline $\begin{array}{l}\text { Jamshidi K } \\
\text { et al. [33] / } \\
2017\end{array}$ & 19 & $\mathrm{~N}$ & $\mathrm{~N}$ & $\mathrm{~N}$ & $\mathrm{~N}$ & $\begin{array}{l}158(25- \\
36)\end{array}$ & $\begin{array}{l}8 \\
(42.1 \%)\end{array}$ & 1 & $\begin{array}{l}\text { Infection (5); sensory, motor } \\
\text { disturbance, or incontinence(11) }\end{array}$ \\
\hline \multirow[t]{2}{*}{$\begin{array}{l}\text { Chen et al. } \\
\text { [21] / } 2018\end{array}$} & 20 & Y & Y & $\mathrm{Y}$ & $\mathrm{N}$ & \multirow[t]{2}{*}{$\begin{array}{l}18.3(3- \\
36)\end{array}$} & $\begin{array}{l}3 \\
(15.0 \%)\end{array}$ & 0 & NR \\
\hline & 10 & $\mathrm{~N}$ & $\mathrm{~N}$ & $\mathrm{Y}$ & $\mathrm{N}$ & & $3(30 \%)$ & 0 & NR \\
\hline \multirow[t]{2}{*}{$\begin{array}{l}\text { Yang et al. } \\
\text { [22]/2018 }\end{array}$} & 6 & $\mathrm{Y}$ & $\mathrm{N}$ & $\mathrm{Y}$ & $\mathrm{N}$ & $12(7-18)$ & $\begin{array}{l}4 \\
(66.7 \%)\end{array}$ & 0 & NR \\
\hline & 10 & $\mathrm{~N}$ & $\mathrm{~N}$ & $\mathrm{Y}$ & $\mathrm{N}$ & $\begin{array}{l}35.3(16- \\
31)\end{array}$ & 0 & 0 & NR \\
\hline \multirow[t]{3}{*}{$\begin{array}{l}\text { Lim et al. } \\
{[34] / 2020}\end{array}$} & 36 & $\mathrm{~N}$ & $\mathrm{~N}$ & $\mathrm{Y}$ & $\mathrm{N}$ & \multirow[t]{3}{*}{$\begin{array}{l}47.7(12- \\
91)\end{array}$} & $\begin{array}{l}12 \\
(33.3 \%)\end{array}$ & \multirow[t]{3}{*}{$2(3.2 \%)$} & \multirow{3}{*}{$\begin{array}{l}\text { Infection (9); delayed wound healing } \\
\text { (11); thrombosis (4); rectal injury (1); } \\
\text { internal iliac injury (1) }\end{array}$} \\
\hline & 9 & $\mathrm{~N}$ & Y & $\mathrm{Y}$ & $\mathrm{N}$ & & $2(22.2 \%)$ & & \\
\hline & 17 & $\mathrm{Y}$ & $\mathrm{Y}$ & $\mathrm{Y}$ & $\mathrm{N}$ & & $3(17.6 \%)$ & & \\
\hline \multirow[t]{2}{*}{$\begin{array}{l}\text { Current } \\
\text { study }\end{array}$} & 13 & $\mathrm{~N}$ & $\mathrm{~N}$ & $\mathrm{Y}$ & $\mathrm{Y}$ & $\begin{array}{l}101.2(81- \\
131)^{-}\end{array}$ & $\begin{array}{l}4 \\
(30.7 \%)\end{array}$ & 0 & \multirow[t]{2}{*}{ Infection (1);wound dehiscence (6) } \\
\hline & 18 & $\mathrm{Y}$ & Y & $Y$ & $\mathrm{~N}$ & $\begin{array}{l}44.9(24- \\
68)\end{array}$ & $\begin{array}{l}2 \\
(11.1 \%)\end{array}$ & 0 & \\
\hline
\end{tabular}

Figures 

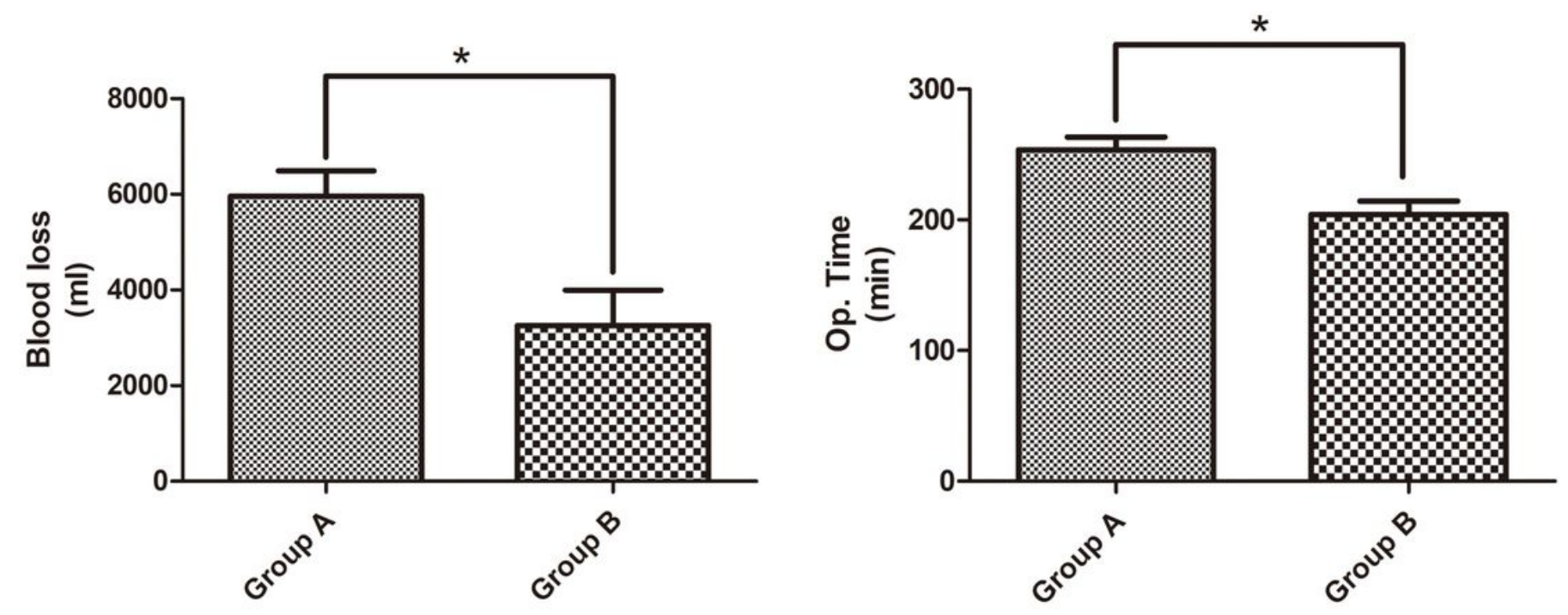

Figure 1

Comparison of intraoperative blood loss $(\mathrm{A})$ and operationtime $(\mathrm{B})$ between groups. $\left({ }^{\star} \mathrm{p} \leq 0.05\right.$ by one-way ANOVA).(SAE: serial arterial embolization)

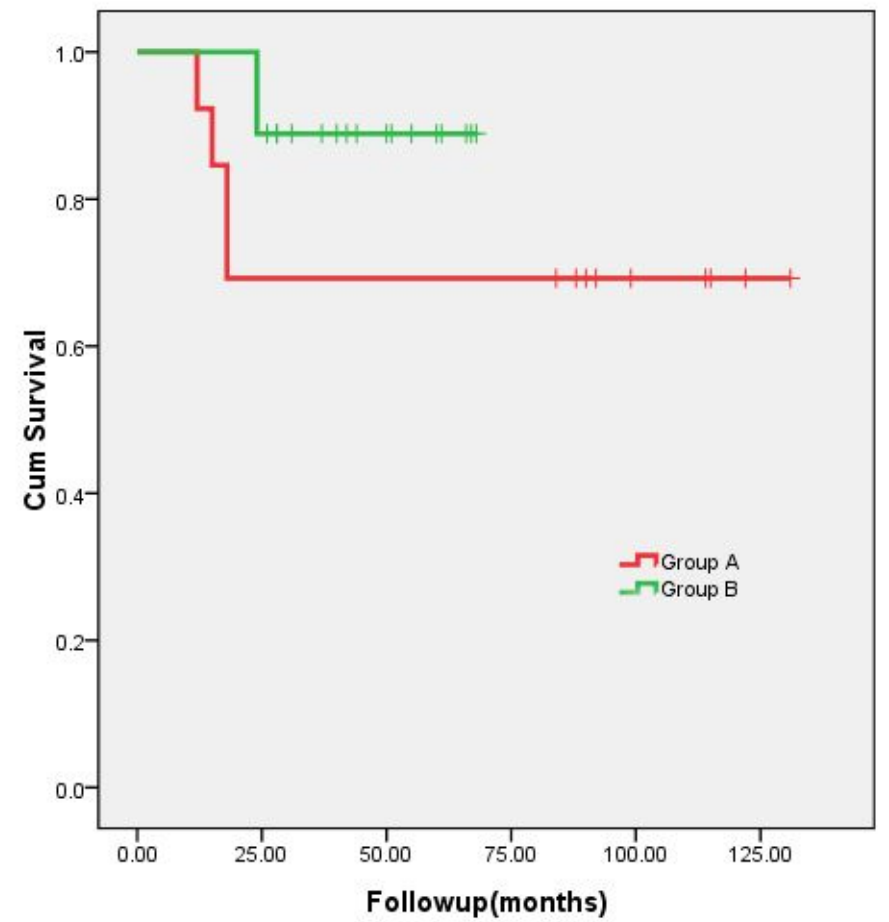

Figure 2

Kaplan-Meier curve of disease-free survival of patients with SGCT in group A and B. (SGCT: sacrum giant cell tumor). 

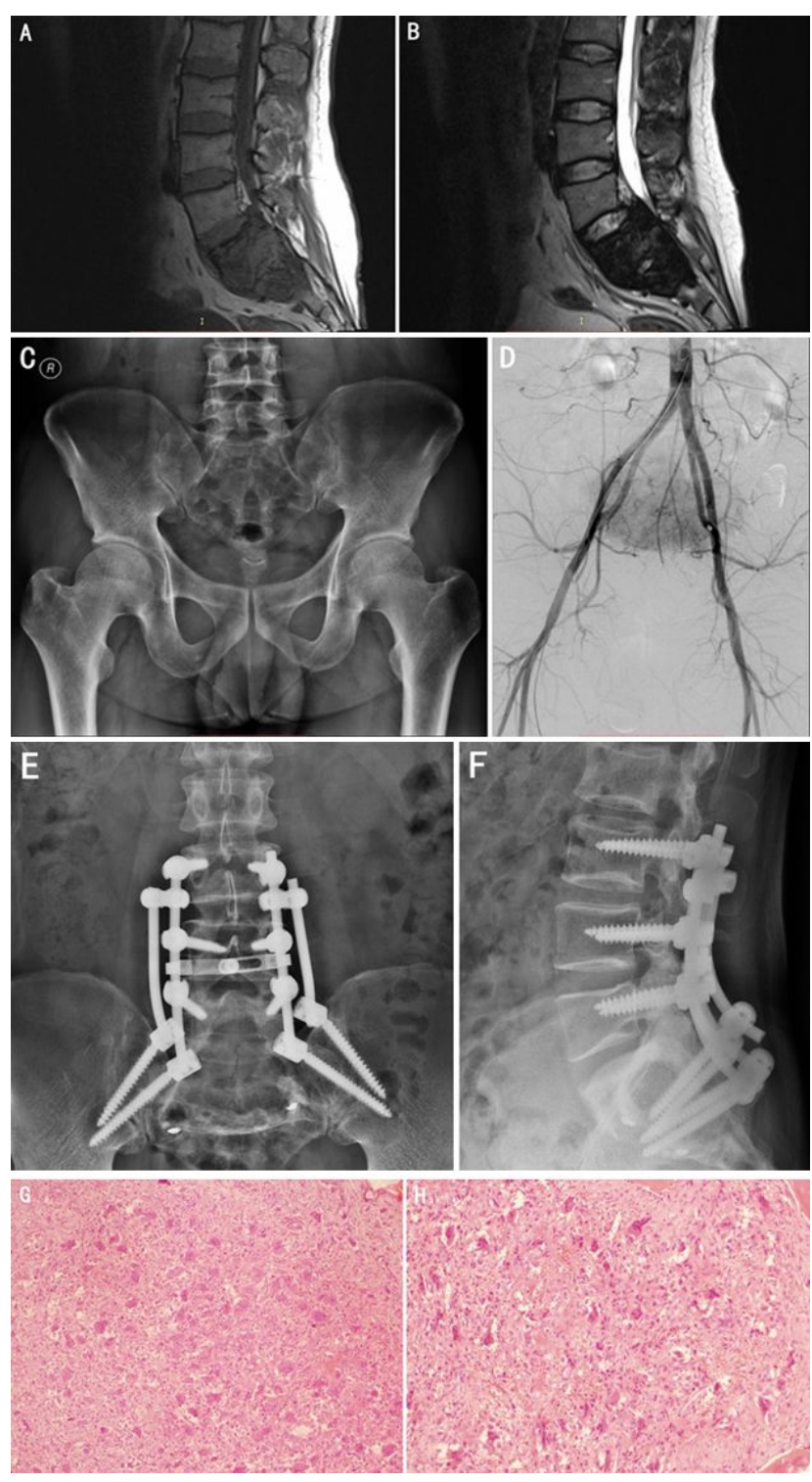

\section{Figure 3}

Sagittal MRI (A: T1-weighted; B: T2-weighted) and X-ray (C) showed a large sacral mass with cortical destruction involving S1-3. Angiographyimage (D) demonstrated the vascularization of the lesion. Postoperativeradiography showed the reconstruction (E-F). The histology indicated that the giant cell number was not significantly reduced before $(G)$ and after SAE treatment $(H)$. 

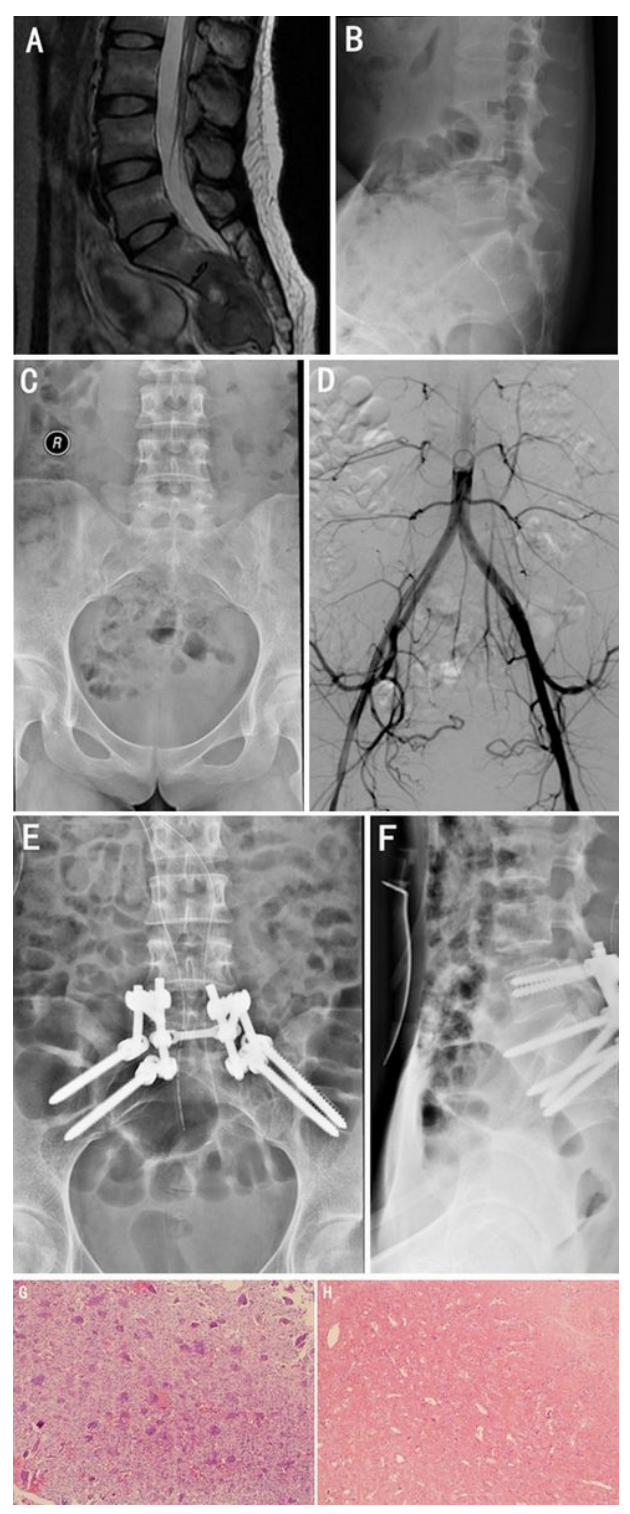

\section{Figure 4}

(A-H) A 22-year-old female with SGCT (involving S1-3 vertebral). Initial MRI scan (A) and radiograph (B, C)demonstrated the tumor lesion. Angiography (D) showed almost non-vascularization of tumor after preoperative denosumab treatment.Postoperativeradiography showed the reconstruction(E-F). The postoperative histology demonstrated the paucity of giant cells and abundant production of fibro-osseous tissue $(\mathrm{H})$ compared to typical GCT histology before denosumab treatment (G). 